\title{
Comparative Study on the Implementation of Accrual-Based Regional Government Accounting Standards at the Human Resources Development Agency of the Province of West Sumatra
}

\author{
Dessy \\ Master of Management, STIE "KBP ", \\ JL Khatib Sulaiman No. 61 Lolong Belanti, \\ Padang Utara 25136, West Sumatra, Indonesia \\ Heryanto \\ Lecturer in Management Master Program, STIE "KBP”, \\ JL Khatib Sulaiman No. 61 Lolong Belanti, \\ Padang Utara 25136, West Sumatra, Indonesia
}

\begin{abstract}
This study aims to compare the implementation of Accrual-Based Regional Government Accounting Standards carried out in the Human Resources Development Agency of West Sumatra Province with the forwarding of Government Accounting Standards according to Permendagri Number 64 of 2013 which refers to PP No. 71 of 2010. The method used in this study is Comparative descriptive research method with qualitative descriptive analysis approach. The data used is secondary data in the form of financial statements in 2015 to 2017 along with transaction evidence and supporting documents related to Accrual Based Accounting. While the primary data was collected through interview methods in order to strengthen the analysis of accrual-based accounting processes in the Human Resources Development Agency of West Sumatra Province. The results showed that the implementation of Accrual-based Regional Government Accounting Standards at the Human Resources Development Agency of West Sumatra Province as a whole was very in accordance with the Minister of Home Affairs Regulation No. 64 of 2013 and PP No. 71 of 2010 with an average level of suitability of $80.69 \%$. Where the financial statements produced are very in accordance with the criteria of financial statements according to Permendagri Number 64 of 2014 with a level of suitability of $83.33 \%$, the recognition process is in accordance with AccrualBased Accounting Standards with a level of conformity of $75.00 \%$, while the process of measurement and presentation Revenue, Expenditures, Expenses, Inventories and Fixed Assets are very much in accordance with Permendagri Number 64 of 2013 which refers to PP No. 71 of 2010 with a level of suitability of $83.75 \%$.
\end{abstract}

Keywords: Accrual Basis, Standard, Government Accounting

\section{INTRODUCTION}

Indonesian government has demonstrated its seriousness in realizing improved quality of performance both physically and financially. The Indonesian as stakeholders welcomed the effort. Communities demand better quality of government performance with a level of transparency, accountability and auditability. Both central and regional governments are expected to be able to present quality accounting information and be able to meet information needs for stakeholders. Reform in the field of accounting is one form of fulfilling the demands of the community for the current performance of the government. Current government accounting is expected to begin to adopt the processes and accounting techniques of the private sector that have previously developed very rapidly compared to public sector accounting. 
In 2005 the Government of Indonesia issued PP No. 24 of 2005 concerning accounting standards based cash towards accrual. The cash towards accrual based accounting standards has actually never been implemented in any country, but because of the government's inability to implement Accrual-Based Accounting Standards directly, then this special standards are need to be developed to implemented during the transition period until the government is fully prepared and mature in applying the Accounting-Based System Full Accrual.

As a form of seriousness, the government then issued Government Regulation of the Republic of Indonesia Number 71 of 2010 concerning Government Accounting Standards which regulate the Application of Accrual-Based Government Accounting Systems and replace the previous Government Regulations, namely PP Number 24 of 2005 concerning Cash-based Accounting Standards Towards Accruals. At Government Regulation Number 71 of 2010 in article 7 paragraph (1) stated that the Accrual-based Government Accounting Standar Implementation will be aplicated in stages start from "Cash towards Accrual"-based accounting system arrived at implemenntation of Accrual-based accounting systems.

According to Government Accounting Standards 01 on Government Regulation Number 71 of 2010, which is meant by the accrual basis is an accounting basis that recognizes the effect of transactions and other events at the time the transaction and event occurs, regardless of when cash or cash equivalents are received or paid. It is different from what has been applied before, namely the cash base that recognizes the influence of transactions and other events when cash or cash equivalents are received or paid. As a follow up to the implementation of the provisions of Government Regulation Number 71 of 2010, at the end of 2013 stipulated a Republic of Indonesia Minister of Home Affairs Regulation Number 64 of 2013 concerning the Application of Accrual-Based Government Accounting Standards for regional government. In this rules at Article 6 it is regulated on Regional Government Accounting System (SAPD) which consists of the Regional Finance Management Officer Accounting System (accounting system of PPKD) and the Regional Work Unit (SKPD Accounting System).

The use of accrual basis is expected to produce more complete financial information so that a transaction can be traced to economic events, and the financial statements produced are more informative for the users. So that in the end a high level of transparency and accountability can be achieved.

Three years since the implementation of accrual-based government accounting systems in regional governments began, there were still some obstacles in its implementation, no exception human resources of accounting that still lacked understanding of accrual-based accounting systems, especially in Regional Organization (OPD) within the scope of Regional Government. As well as the application of information systems that are still imperfect in the application of accrual-based accounting systems that are currently running. These constraints result in the possibility of implementation that has not been in accordance with what should be. These constraints are certainly a form of government unpreparedness in implementing accrual-based SAP.

The lack of knowledge of Human Resources about accrual-based accounting, especially in the Human Resources Development Agency of the Province of West Sumatra raises doubts for the author to the readiness and maturity of West Sumatra Province in implement the AccrualBased Accounting Standards. Where the implementation of the Accrual-based Accounting Standards just began to be implemented in 2015 . 
This study aims to analyze the implementation of accrual-based Regional Government Accounting Standards in the Human Resources Development Agency of the Province of West Sumatra by describing the financial statements produced in the 2015, 2016 and 2017 budgetaring years, the process of recognizing income, expenditure, expenses, inventory and fixed assets accounts, and the process of assessing, measuring and presenting income, expenditure, expenses, inventories and fixed assets accounts, then comparing them with Accounting Standards regulated in Minister of Home Affairs Regulation Number 64 of 2013 and Government Regulation Number 71 of 2010.

\section{LITERATURE REVIEW}

Adopting the opinion of Jensen and Meckling (1976) about agency theory, in the context of government and society can be described that the relationship between government and its people can be said to be an agency relationship. Where that relationship arises because of the contract between the community as pincipal and the government as the agent. If both parties have the same goal, it can be believed that the government as the agent will act in a manner that is in accordance with the interests of its people (as the principal).

To ensure that the government has acted on its contract with the community, it is important for the community to demand that the government make a report as a form of accountability for the contract they have agreed to. This is in accordance with Government Regulation Number 8 of 2006 concerning Financial Reporting and Performance of Government Agencies which explains that both the central and regional governments are obliged to prepare and present Financial Reports and Performance Reports in the framework of accountability for the implementation of the State Budgetary (APBN) / Regional Budgetary (APBD).

\section{Government Accounting}

Government accounting which in several literars is also called public sector accounting is an important information tool for the government as management and also as an information tool for the public. Public sector accounting is related to three main things, namely the provision of information, management control, and accountability (Mardiasmo, 2009, p.14).

Before the state financial management reform, the implementation of government accounting at that time had been implemented with a single entry recording system. As a result, the government does not have a record of accounts receivable and debt, let alone a record of fixed assets held and equity. The use of the cash basis causes the government not to display the balance sheet as a form of financial statements to describe its financial position. According to Bastian (2006), the cash base only recognizes cash inflows and outflows. The final financial account will be summarized in the cash book, so that financial statements cannot be produced due to the absence of data about assets and liabilities.

To support state financial reform, the government then issued law number 15 of 2004 concerning the Examination of Responsibility and Management of State Finance. The law was then strengthened by the enactment of Government Regulation Number 24 of 2005 concerning Government Accounting Standards. After establishing this Government Accounting Standard, the government must prepare a complete financial report as a form of accountability for government financial management. The single entry recording system that has been used so far, is no longer possible to implement because it does not produce more complete financial reports, inevitably the government must switch to a double entry system (Tanjung, 2013)

The government's seriousness in realizing the application of a full accrual-based accounting system is increasingly clear with the issuance of Government Regulation Number 71 of 2010 
concerning Accrual-Based Government Accounting Standards. In accrual-based accounting standards there are several important issues of change that need to be understood (Tanjung, 2013, pp.6-7), among others are :

I. Basic financial statements according to Government Regulation number 24 of 2005 consist of Budget Realization Reports, Balance Sheets, Cash Flow Reports, and Notes to Financial Statements. Whereas in Government Regulation number 71 of 2010 the components of financial statements are added to the Budget Realization Report (LRA), Reports of Changes in More Budget Balances (SAL Change Reports), Balance Sheets, Operational Reports (LO), Cash Flow Reports (LAK), Equity Change Reports ( LPE), and Notes to Financial Statements (CaLK)

II. Relationship between financial statements are divided into Financial Reports (Operational Reports, Changes in Equity Reports, Balance Sheet) and Budget Implementation Reports (Budget Realization Reports, Changes to Balance Reports, Budget Over)

III. The recording basis used in the Government Accounting Standards according to Government Regulation number 24 of 2005 is the Cash Towards Accrual basis, while the Government Accounting Standard according to Government Regulation number 71 of 2010 is the Accrual Base.

IV. In the preparation of the Budget Realization Report, the government continues to use the cash basis, while the preparation of the Balance Sheet and Operational Report uses an accrual basis.

Government Accounting Standards are requirements that have legal force in an effort to improve the quality of government financial reports in Indonesia (Hariadi et al., 2010, p.113). The application of Government Accounting Standards is believed to have an impact on improving the quality of financial reporting in central and regional governments, so that government financial information can be used as a basis for decision making by the government. Accrual-Based Government Accounting Standards are Government Accounting Standards that recognize income, expenses, assets, debt, and equity in accrual-based financial reporting, as well as recognizing income, expenditure and financing in reporting budget execution based on the basis stipulated in the Regional Budget / APBD (Minister of Home Affairs Regulation Republic of Indonesia Number 64 of 2013).

Accounting system according to Warren et al. (2005, p.234) are methods and procedures for collecting, clarifying, summarizing, and reporting on a company's operational and financial information. Regional Government Accounting System (SAPD) is a systematic series of procedures, organizers, equipment and other elements to realize the accounting function since the analysis of transactions up to financial reporting within the local government organization. The Regional Government Accounting System (SAPD) consists of the Regional Finance Management Office Accounting System (PPKD Accounting System) and the Regional Work Unit Accounting System (SKPD Accounting System). The scope of accounting policies applies to reporting entities and accounting entities in preparing financial statements. The reporting entity is the local government, while the accounting entity is a Regional Work Unit / SKPD and Finance Management Office / PPKD (Permendagri 64 Tahun 2013, Annex I). An accounting entity is a unit of government of budget users / users of goods that is obliged to carry out accounting and prepare financial statements to be combined with a reporting entity. While a reporting entity is a government unit consisting of one or more accounting entities or reporting entities which according to statutory provisions must submit reports accountability in the form of financial statements. 
In paragraph 84 of the Conceptual Framework of Government Accounting Standards in Module 1 - Concepts and Accounting Cycles in Local Governments, it is explained that recognition in accounting is the process of the determining fulfillmented of criteria recording of events that change elements of assets, liabilities, equity, income - Budget Realization Reports, spending , financing, income-Operational Reports, and expenses, as will be contained in the financial statements of the reporting entity concerned. Measurement is the process of determining the value of money to recognize and enter each post in a financial report. The measurement of items in the financial statements uses historical acquisition values. Assets are recorded at the amount of economic resource expenditure / use or equal to the fair value of the benefits given to obtain the asset. Obligations are recorded at the fair value of economic resources used by the government to fulfill the obligations in question (Attachment I of Minister of Home Affairs Regulation Number 64 of 2013).

\section{Income Accounting}

In Government Regulation Number 71 of 2010, there are 2 terms of income, namely Income of Operational Reports and Income of Budget Realized Reports. Income - Operational Report is the right of the regional government that is recognized as an increase in equity in the period of the relevant budgetary year and does not need to had been repaid. While Revenue-LRA is all receipts of State / Regional General Cash Accounts that add the Budget Balance More in the period of the relevant budgetary year which is the government's right, and does not need to be repaid by the government (Director General of Regional Financial Development of the Ministry of Home Affairs, Module 2- Accounting Policy Local Government, Chapter 1).

LO income is recognized when the rights arise on income or when the income is realized. Whereas LRA's income uses a cash basis, so it is recognized when cash is received in the Regional General Cash account, or received by the Regional Work Unit (SKPD), or received by other entities outside the regional government on behalf of the Regional General Treasurer / BUD (Permendagri Number 64 of 2013).

\section{Expenditure Accounting}

Regional Expenditures are all expenditures from the Regional General Cash Account that reduce the Budget Balance More (SAL) in the period of the relevant budget year, which the government will not receive repayments (PP No. 71 of 2010).

In attachment I Permendagri Number 64 of 2013 explained that expenditure is recognized at the time of expenditure from the Regional General Cash Account, specifically for expenditures through expenditure treasurers recognition of expenditure occurs when accountability for expenditures authorized by Budget Users, expenditure accounting is carried out based on gross principle and measured based on the nominal value issued and stated in the legal expenditure document. In financial statements, expenditure is presented in the Budget Realization Report (LRA) after the Income account.

\section{Expense Accounting}

Expenditures are a decrease in economic benefits or service potential in the reporting period which decreases equity, either in the form of asset expenditure or consumption or the emergence of obligations (Government Regulation Number 71 of 2010). The burden can also be said as a government obligation that is recognized as a deduction from net worth. Expenses according to economic classification for regional governments consist of employee costs, goods costs, subsidy expenses, grant expenses, social assistance expenses, depreciation of fixed assets / amortization, transfer fees, and unexpected costs. 
Expenses according to Government Regulation Number 71 of 2010 are recognized when the obligation arises, namely when the transfer of rights from another party to the government is not followed by the issuance of cash from the regional general cash, or the consumption of assets, namely when cash is disbursed to other parties, and or consumption of non-cash assets in government operations, or a decrease in economic benefits or service potential, namely when there is a decline in the value of assets in connection with the use of the asset in question / the passing of time. In financial statements, expense accounts are presented in the Operational Report (LO).

In recording the recognition of this cost there are two approach methods, namely the Cost Approach Method where each purchase of goods and services will be recognized/recorded as an expense if the purchase of goods and services is intended for immediate use or consumption, and the Asset Approach Method where each purchase goods and services will be recognized /recorded as inventory if the purchase of goods and services is intended to be used in one budget period or for its nature just in case.

Corrections of expenses (return receipts) incurred in the current period are recorded as deduction from expenses in the current period. Revenue was borne by the previous year (Director General of Financial Balance of the Ministry of Finance of the Republic of Indonesia, 2014).

\section{Inventory Accounting}

Inventories are current assets in the form of goods or equipment intended to support the operational activities of regional governments, or goods intended to be sold and delivered in the context of service to the community (PSAP BA 05 Government Regulation Number 71 of 2010). There are two ways of recognizing inventories, which are recognized when the potential for future economic benefits are obtained by the government and have values or costs that can be measured reliably, or recognized when received or ownership and ownership shifts.

Often there is a difference in inventory between inventory records according to the treasurer of the goods / management of goods or inventory records according to the accounting function with the results of stock taking. Inventory differences can be caused by inventory loss, obsolescence, expiration, or damage. If the inventory difference is considered as a normal amount, then the difference in inventory is treated as an expense. If the inventory difference is considered as an abnormal amount, then this inventory difference is treated as regional loss.

The principle of recognition and measurement of inventories is that inventories are valued by physical calculation at the end of the period, inventories derived from purchases are valued based on standard costs, inventories obtained by other means such as grants or spoils valued at reasonable and the ending inventory balance is calculated based on the latest purchase price (Directorate General of Financial Balance of the Ministry of Finance of the Republic of Indonesia, 2014).

\section{Fixed Asset Accounting}

Fixed assets are tangible assets that have a useful life of more than 12 months to be used, or intended to be used in government activities or utilized by the general public (PSAP BA Number 07, Government Regulation Number 71 of 2010). In Accounting for Fixed Assets this is also known as depreciation. Assets used by the government except certain types of assets such as land, have limited useful life and capacity. As the capacity and benefits of an asset decrease, 
value adjustments are made. Depreciation is a systematic allocation of the value of a depreciable asset during the useful life of the asset in question.

The measurement of fixed assets must pay attention to the policies of the local government regarding the provisions of the minimum unit value of fixed assets. If the acquisition value of a fixed asset is below the minimum unit value of capitalization, then the fixed assets cannot be recognized and presented as fixed assets, but still disclosed in the Notes to the Financial Statements. Minimum Unit Value Capitalization for acquisition costs is the total new procurement expenditure. The value of the Minimum Unit for Fixed Asset Capitalization is excluded from expenditures for land, roads / irrigation / networks, and other fixed assets in the form of library collections and art-style items, equipment for the teaching and learning process. The minimum value of the capitalization of fixed assets and their types is determined by the regional head.

Other Fixed Assets in the form of animals, plants, and library books are not depreciated periodically, but deletion is applied when the Other Fixed Assets are already unusable or dead In terms of presentation, fixed assets are presented in the balance sheet based on its cost less accumulated depreciation. In the event of a condition that allows revaluation, the fixed assets will be presented with adjustments to each fixed asset and equity account. In financial statements, these fixed assets accounts are presented in the balance sheet.

\section{RESEARCH LOCATION}

This comparative study was conducted at one of the regional government agencies in the West Sumatra Province, namely the Human Resources Development Agency. Where this agency has started implementing Accrual-Based Government Accounting Standards since the last three years, namely 2015. The object of this research is the implementation of accrual basis accounting standards in the Human Resources Development Agency of the Province of West Sumatra. In this comparative study the authors will examine three aspects related to accrualbased accounting, namely the financial statements produced, the process of recognizing accounts in the financial statements and the process of assessing, measuring and presenting accounts of income, expenditure, expenses, inventories and fixed assets.

\section{Research Context}

\section{RESEARCH METHODOLOGY}

According to Priadana and Muis (2009, p.15), descriptive research is research that aims to express a situation systematically in a particular field that is at the center of the researchers' thinking in fact. Descriptive studies are conducted to understand the characteristics of organizations that follow certain general practices (Sekaran, 2006, p.158). In this study the author tries to describe in full and accurate how the implementation of Accrual-Based Accounting Standards carried out in the Human Resources Development Agency of the Province of West Sumatra in 2015, 2016 and 2017, which is the first three years at the beginning of SAP Implementation West Sumatra province. Based on the description above, it can be categorized that this research belongs to the type of descriptive research.

Because this research was conducted by comparing the practice of applying SAP-based to the Human Resources Development Agency of the Province of West Sumatra with the applicable Regulations namely Permendagri Number 64 of 2013 and referring to Government Regulation No. 71 of 2010, the method used in this study is a comparative descriptive research method. 


\section{Measurment and Research Instruments}

The comparative descriptive analysis method is used to determine the level of suitability between the theory used and the applicable legislation with the actual conditions of the research focus. Measurement and data processing is done first by setting several criteria as research instruments. The criteria were developed based on Permendagri No. 64 of 2013 and PP No. 71 of 2010 to be 14 criteria for evaluation of Accrual Based Financial Reports, 16 evaluation criteria for recognition of accounts in Accrual Based Financial Statements, and 42 evaluation criteria for evaluating, measuring and presenting accounts in Accrual Based Financial Reports consisting of 6 income accounting criteria, 7 expenditure accounting criteria, 9 expenses accounting criteria, 9 inventory accounting criteria and 11 criteria for fixed asset accounting.

Each item criteria set above is then compared with the implementation that has been carried out in the Human Resources Development Agency of the Province of West Sumatra in the 2015-2017 fiscal year. If appropriate, a value of 1 will be given, but if not appropriate, a value of 0 . The results of this evaluation are then calculated by making a percentage of the level of conformity and then described. The level of conformity is calculated by dividing the total value obtained from the evaluation results in each year with the total evaluation criteria set, then used as a percentage. The results of the evaluation on each criterion are then averaged to obtain conclusions of the suitability of the three years analyzed. The three-year conformity level is then averaged to obtain conclusions on the implementation of Accrual-Based Accounting Standards for the Human Resources Development Agency of West Sumatra Province as a whole.

\section{ANALYSIS AND RESULTS}

The comparative study of the Implementation of Government Accounting Standards in BPSDM of West Sumatra Province on Permendagri Number 64 of 2013 and PP No. 71 of 2010 resulted in an average rate of conformity of $80.69 \%$. This shows that the implementation of AccrualBased Government Accounting Standards in the Human Resources Development Agency of West Sumatra Province can be said to have been very in accordance with Permendagri No. 64 of 2013 and PP No. 71 of 2010 . The average level of conformity is obtained from the evaluation of the completeness of financial statements with a value of $83.33 \%$, the evaluation of the process of recognizing accounts in financial statements is $75 \%$ and the results of evaluations of the process of measurement, assessment and presentation of accounts in the financial statements amount to $83.75 \%$.

Based on the research objectives, the results of this comparative study are described as follows:

1. The financial report of the Human Resources Development Agency of West Sumatra Province has met the criteria in accordance with Permendagri Number 64 of 2013 and Government Regulation Number 71 of 2010 with a level of conformity of $83.33 \%$. A little significant difference is found in the CaLK Report format, where the CaLK of the Human Resources Development Agency of the Province of West Sumatra is prepared in the format of Financial Reports for reporting entities, whereas in fact the Human Resources Development Agency of the Province of West Sumatra is an accounting entity (SKPD) not a reporting entity (Regional Government). The difference occurs because BPSDM of West Sumatra Province in compiling its financial statements refers to Pergub Number 43 of 2014, wherein the Governor Regulation does not explain the difference in the format of the CaLK SKPD (accounting entity) with the Local Government CaLK (Reporting Entity). Governor Regulation Number 43 of 2014 only contains one type of 
CaLK Report format which is systematically written similar to the Local Government CaLK (reporting entity) according to Permendagri Number 64 of 2013.

2. Regarding the process of recognizing accounts in financial statements, it is concluded that the Human Resources Development Agency of the Province of West Sumatra has implemented Accrual-Based Accounting Standards in accordance with Permendagri Number 64 of 2013 and Government Regulation Number 71 of 2010, with a conformity level of $75.00 \%$. There are several discrepancies, namely LO income is not recognized when the income is realized but waits when Cash is received (cash basis). Likewise, expenses on employees whose recognition is still waiting when the cash comes out of the account, not when the obligation / issue of SP2D arises (for the LS mechanism) and not when the proof of payment of expenses has been approved by the Budget User (for UP / GU mechanism). Similarly, the load of goods that have not been recognized when the receipt / receipt of goods is signed, but still waiting when payment is made (cash basis).

3. For the process of measuring, evaluating and presenting income, expenditure, expense, inventory and fixed assets accounts, it can be concluded that the implementation of Accrual-Based Accounting Standards in the Human Resources Development Agency of West Sumatra Province has been very in accordance with Permendagri Number 64 of 2013 and PP Number 71 of 2010, with an average level of conformity of $83.75 \%$. Of the five accounts studied, $100 \%$ (very appropriate) for income accounts were obtained, $90.48 \%$ (very suitable) for expenditure accounts, $77.78 \%$ (accordingly) for expense accounts, $77.78 \%$ (accordingly) for inventory accounts and 72.73\% (accordingly) for fixed asset accounts.

The most fundamental constraints faced by the Human Resources Development Agency of the Province of West Sumatra in implementing Accrual-Based Government Accounting Standards include:

1. Lack of in-depth understanding of accrual-based accounting, especially for staff related to the function of accounting and administration of assets.

2. The application used as an information system for accounting records is different from the application used as an information system and administration of assets. Both of these applications are not mutually integrated, resulting in frequent misinformation that causes differences between the notes on the asset section and the records made in accounting and finance.

\section{DISCUSSION AND CONLUSIONS}

The results of this comparative study show that the average rate of conformity is $80.69 \%$, which means that the implementation of Accrual-Based Accounting Standards in the Human Resources Development Agency of the Province of West Sumatra has been implemented in accordance with Permendagri Number 64 of 2013 and Government Regulation No. 71 of 2010. The level of suitability for each evaluated object is described as follows:

1. As much as $83.33 \%$ of the 14 Accrual Based Financial Report criteria have been met (very suitable).

2. As much as $75.00 \%$ of the 16 criteria for the Recognition of accounts in the Financial Report have been fulfilled (accordingly).

3. As much as $83.75 \%$ of the total 42 criteria for evaluating the process of measuring, evaluating and presenting accounts in the financial statements (very appropriate). These accounts consist of:

a. Income, with the evaluation results of $100 \%$ conformity

b. Expenditure, with the results of evaluation of the suitability level of $90.48 \%$ 
c. Expenses, with the evaluation results of a level of conformity of $77.78 \%$

d. Inventory, with evaluation results of a level of conformity of $77.78 \%$

e. Aset Fixed, with the evaluation results of a suitability level of $83.75 \%$

Of the various problems and constraints found in the application of Accrual-Based Accounting Standards in the Human Resources Development Agency of West Sumatra Province, with the hope that in the future this Accrual-Based Accounting Implementation can be carried out better and in accordance with applicable standards. For this reason, the authors recommend the following:

1. Provide more specific training to all staff related to the implementation of financial accounting and asset functions, in order to gain a deep understanding and equalization of perceptions to present more accurate information so that the implementation of Accrual-Based Government Accounting Standards can work better.

2. Provide an understanding of the accrual-based accounting system to staff who carry out the Planning function to avoid errors in budgeting related to accrual-based accounting. As is known that the application used in budgeting is the same information system and has been integrated with the accounting information and financial reporting system, so that if there is an error in planning and budgeting it will also result in misstatement in financial reporting.

3. The Government of West Sumatra Province should use an asset information system that has been very well integrated in accounting and financial information systems. It is proposed that the capital expenditure recording system can be directly connected automatically to the asset administration system. So that the amortization of assets and book value can be immediately detected and journalized in the financial reporting system. Likewise for assets that have expired so that they can be directly identified and reclassified on other asset accounts in a timely manner, so that the decision to revaluate or eliminate assets becomes faster.

4. The concern of all parties towards the implementation of Accrual-Based Accounting Standards is needed so that all data and information collected in the context of the preparation of these accrual-based financial statements becomes more precise, actual and accurate.

5. It was suggested to the Government of the Province of West Sumatra to conduct a review in order to improve and improve Governor Regulation No. 43 of 2014 concerning Accounting Policies, Accounting Systems and Standard Account Charts of the West Sumatra Provincial Government to be more adapted to the applicable Accrual Based Accounting Standards, namely Permendagri Number 64 of 2013 and Government Regulation No. 71 of 2010.

\section{Study Limitations}

Due to the limitations of the research time, and not allowing it for the author to discuss the entire post in the financial statements, the author focuses this research only on certain accounts whose recording, valuation and measurement will be affected by the application of Accrual SAP. These items include income, expenditure, expenses, inventories and fixed assets. The four posts above are expected to represent all accounts in the Accrual Based Financial Report.

From the limitations of this study, it is expected to inspire new researchers to conduct similar research but with more in-depth studies related to the Implementation of Accrual-Based Government Accounting Standards. 


\section{Reference}

Bastian, Indra. 2006. Akuntansi Sektor Publik : Suatu Pengantar. Erlangga, Jakarta.

Descopa, Vilentina. 2015. Evaluasi Penatausahaan Aset Tetap Pada Pemerintah Kota Payakumbuh. Tesis Magister Akuntansi. Universitas Andalas. Padang.

Direktorat Jenderal Bina Keuangan Daerah Kementerian Dalam Negeri. 2014. Modul Penerapan Akuntansi Berbasis Akrual pada Pemerintah Daerah. keuda.kemendagri.go.id/.../modul...akuntansi.../modul2. Jakarta.

Gubernur Sumatera Barat. Peraturan Gubernur Sumatera Barat Nomor 43 Tahun 2014. Tentang Kebijakan Akuntansi, Sistem Akuntansi dan Bagan Akun Standar Pemerintah Provinsi Sumatera Barat. Padang.

Hariadi, Pramono. Restianto, Yanuar E. Bawono, Icuk Rangga. 2010. Pengelolaan Keuangan Daerah. Salemba Empat, Jakarta

Jensen, M. dan W. Meckling. 1976. "Theory of the Firm: Managerial Behavior Agency Cost and Ownership Structure”. Journal of Finance Economics 3: 305-360

Kementrian Dalam Negeri. Peraturan Menteri Dalam Negeri Nomor 64 Tahun 2013. Tentang Penerapan Standar Akuntansi Pemerintahan Berbasis Akrual Pada Pemerintah Daerah. Fokusindo Mandiri. Bandung.

Kementerian Keuangan RI, Direkorat Jenderal Perimbangan Keuangan. 2014. Modul Akuntansi Keuangan Pemerintah Daerah dan SKPD. Jakarta.

KSAP. Peraturan Pemerintah No. 24 Tahun 2005. Standar Akuntansi Pemerintahan, Jakarta.

. Peraturan Pemerintah No. 71 Tahun 2010. Standar Akuntansi Pemerintahan. Fokusmedia, Bandung.

Mardiasmo. 2009. Akuntansi Sektor Publik. Cetakan Keempat. ANDI, Yogyakarta.

Pemerintah Republik Indonesia. Undang-undang No. 15 Tahun 2004. tentang Pemeriksaan Tanggung Jawab dan Pengelolaan Keuangan Negara, Jakarta.

Instansi Pemerintah, Jakarta.

. Peraturan Pemerintah No. 8 Tahun 2006. tentang Pelaporan Keuangan dan Kinerja

Priadana, H. Moh. Sidik. Muis, Saludin. 2009. Metodologi Penelitan Ekonomi \& Bisnis. Graha Ilmu, Yogyakarta.

Sekaran, Umma. 2006. diterjemahkan oleh Kwan Men Yon, Edisi 4, Buku 1. Research Methods For Business. Penerbit Salemba Empat.

Tanjung, A. Hafiz. 2012. Akuntansi Pemerintahan Daerah Berbasis Akrual; Pendekatan Teknis Sesuai PP No. 71/2010. Alfabeta, Bandung.

Warren. Reeve. Fees. 2005. Accounting (diterjemahkan oleh Aria Farahwati).

http://ilmuakuntansi.web.id/pengertian-sistem-akuntansi. 